\section{"DIABETES FOLLOWING INFLUENZA."} To the Eaitors of THE LANCET.

Srrs, -The case of diabetes $I$ reported in THE LANCET of April 2nd, 1892 has, I regret to write, not recovered as $\mathbf{I}$ had hoped at the time. The urine was quite free from sugar for a month before he was discharged from hospital, and he was on the ordinary full diet during that period. He proceeded on a sick furlough for two months, but on his return he again reported himself as "sick" and his sympioms were as severe as at first. He was subsequently invalided from the service and is now residing in the country at my suggestion, but is in a miserable condition and unable to do any work whatever. Directly my report appeared in THE LANCET I received a letter from Dr. Saundby advising me to continue looking after this man carefully, as in his experience these cases did not recover, and in this case it has proved to be correct.

I am, Sirs, yours truly,

$$
\text { Dover, Jan. 31st, } 1893 .
$$

J. HoYsTED

\section{"THE TREATMENT OF MYXOEDEMA."}

\section{To the Eatitors of THE LANCET.}

SIRs, - In a leading article in THE LAxceT of Feb. 4th, on the Treatment of Myxœdema, it is stated that "as to the best form of administration, seeing that such excellent results are obtained by the simple consumption of the thyroid gland, it would seen unnecessary to use it in the form of extracts for hypodermic injections, or even as a powder for administration by the mouth." I would point out that there is a great advantage in being able to give the remedy in so simple and portable a form as that of the powder. I refer especially to the treatment of such cases as out-patients, who have considerable difficulty in obtaining thyroid glands; there is also the further risk of their being diseased, as pointed out by Dr. Alex. Napier, and as the glands very quickly undergo decomposition after the animal is killed, the importance of getting them fresh is obvious. All these contingencies are avoided by administering the thyroid extract in the form of a powder, which has also the further advantage, according to my experience, of causing scarcely any nauseating effects such as are liable to be produced by giving the glands raw or cooked. I should say that I always strictly enjoin my patients to rest at least an hour after taking the powder, on account of the liability to syncope, as shown by Dr. Murray in such cases, after injection. On the advantages of this method over that of hypodermic medication I need not dwell. I take this opportanity of acknowledging my indebtedness to Dr. Hector Mackenzie for suggesting the use of the powders and to Mr. Edmund White, B.S.C., F.I.C., for the original way in which he has so ably prepared them.

I am, Sirs, yours truly,

Finsbury-square, E.C., Feb. 7th, 1893. ARTAUR T. DAVIES.

\section{DENTAL A D V ERTSING. \\ To the Editors of THE LANOET.}

SIRs, - I enclose a copy of a petition to the General Medical Council which has already received about fifty signatures, and shall be glad if you can find it a place in THE LANCEx and afford it any support you may feel able to give. I think the General Medical Council will feel that we dentists appreciate their endeavours to elevate our branch of the profession, and will further relieve us in the manner indicated in the petition. At all events, if we can enlist the sympathy of the general body of medical men we shall be able to present a strong and united front all the sooner.

I am, Sirs, yours truly,

Postern-street, Nottingham, Feb. 7th, 1893. HENRY BLANDY. PETITION

of Registered Dentists of Great Britain and Ireland to the General Medical Council.

May it please your honourable Council.

We the undersigned Registered Dentists believe that a person who is registered as a dentist is guilty of infamous and disgraceful conduct in a professional respect if he conduct his practice by means of the exhibition of dental appliances or apparatus in an open shop, or in a window or in a show case exposed to public inspection, or if he seek to attract attention by means of public advertisements, or circulars describing modes of practice, or patented or secret processes, or by the publication of a scale of professional charges: we therefore humbly ask your honourable Council to purge o $r$ profession from any such degrading persons by removing their names from the Register and also the names of any registered dentists who may be associated as assistants or managers with persons not themselves registered who "rode under the style of "Dental Institute" \&c., and who are "covereds" aided and abetted by the said registered dentists. We further beg your bonourable Council to accept as proof of such infamous and disgraceful conduct production of the alvertisement or circular, photcgrayths or draw ngs of the exlibits or signs, sworn to by at least two affida viv, and such testimony as would be conclusive in a court of law.

And your petitioners will ever pray \&c.

$$
\begin{aligned}
& \text { your petitioners will ever pray \&c. } \\
& \text { Name. }
\end{aligned}
$$

\section{THE TREATHENT OF ASIATIC CHOLERA。}

\section{To the Editors of THE LANCET.}

Sirs, - The interesting communication cif SnrgeonLieutenant-Colonel Duke in your last issue leais rie to the following narrative of experience. As cholera was progressing westward from New York in 1867 the inhavitants of the great inland cities of the United States were in much alarm, and provided themselves generally with one or arother of the so-called "cholera mixtures," of which the most rocpular was. that containing equal parts of the tinctures of oninum, cam. phor and rhubarb. When the disease actually arfeared in our midst, practitioners usually found their ravients had already put themselves under the full influence of tyese drugs before seeking advice, and many were stupil wh opium. In my own clientile such cases speedily succurbed, as it appeared, largely because of a medicinal aggravation of the glandular and secretory torpor characterising the wime vios during the course of the attack. Sir George Johnson's views of the necessity for eccoprotics had at that tirne awakened attention, but the laity strongly objected to such a reversa of older and accepted theories and simply would not take castor-oil. The writer adopted a middle corrse before the first week of the epidemic had expired, giving a nowder or a freshly made pill of calomel, one-sixth of a srin, piperine one-quarter of a grain, and sugar of milk, three grains, every ten, fifteen, or twenty minutes pro re natâ, uritil freculent matter ("floating islands") appeared in the stosls. The. early successes of this plan were so decided as to gain for it much confidence. To the cest of my recollection not a patient was lost after its adoption unless previously saturated with opium or tco far gone for any hopeful medication. It was a notable fact that typhoid states, so apt to follow the more acute stages of cholera. were seldom or never observed in cases so treated, and that convalescence was both rapid and uninterrupted. Proof was not lacking in the experience of my colleagues that niperine was a valuable adjunct to the mercury, the more so if cases were far advanced before being seen, and that small and frequent doses of both were preferable to larcer and more divided ones. I am, Sirs, yours very respect fu? Cavendish Mansions, Feb. 8th, 1893.

\section{"CANCER AND SARCOMA CALSED BY PSOROSPERMS." \\ To the Eaitors of THE LANCET.}

SIns,-My attention has been drawn to a letter by Dr. Armand Ruffer which appears in THE LANCEm of Feb. 4th, and which refers to a passage in the report of the proceedings of the Pathological Society of Jan. 17th. The coservation I made was not "gratuitous," since it was in arswer to a statement made in the discussion by Dr. Gailoway to the effect that the bodies I described as psorosperms were not like those described by Dr. Ruffer. I have referred to my notes and I find that I said (giving reasons) that the article by Ruffer and Walker, published in the second number of the Journal of Pathology and illustrated by Metchrikoff and Ruffer, was retrograde in the sense that it was sar behind the work of many previous observers. This opinion 1 stilk hold. With regard to Dr. Ruffer's remarks as to the "extraordinary" statements made in one of my papers, I would say that it would have been more discreet to have withheld them until Dr. Ruffer was prepared to discuss the matter fairly.

In the same issue is published an article by Dr. Galloway. entitled "Parasitism of Protozoa in Carcinoma," and therein he refers to the question of the presence of protozoa in sarcoma as being "now under consideration." Seeing that Dr. Galloway was present at the meeting of the Pathological Society on Jan. 17th, 1893, at which I showed drawings of, and described psorosperms in, sarcomata, I can ory conclude 